\title{
Ambient air quality and human health: Current concepts Part 2
}

\author{
TEE L GUIDOTTI MD MPH FRCPC CCBOM \\ Department of Public Health Sciences, University of Alberta Faculty of Medicine, \\ Edmonton, Alberta
}

TL GUIDOTTI. Ambient air quality and human health: Current concepts, Part 2. Can Respir J 1996;3(1):29-39.

This second of two parts continues with the development of a framework for understanding air quality issues and their relationship to human health. Recognized health effects associated with air pollution are described and current controversies regarding ozone and $\mathrm{PM}_{10}$ are briefly outlined. Epidemiological methods of investigating air quality effects are discussed, comparing recent landmark studies in Canada. Comparative prevalence studies do not reflect the state of the art in air pollution epidemiology but are frequently cited and conducted in Canada as if they were definitive. The implications of setting air quality standards and objectives on this basis or to meet arbitrary levels of risk of health effects are examined. The current state of the art does not support risk-based air quality standards. A policy of continuous improvement is most protective of both human health and the environment.

Key Words: Air pollution, Air quality, Health

\section{HEALTH EFFECTS AND AIR QUALITY}

Current thinking about air pollution has been shaped in the past by several catastrophic exposure incidents earlier in this century. Air pollution has been associated in these severe episodes with high mortality, usually among persons with pulmonary or cardiovascular disorders (1). These air pollution catastrophes have been extensively studied and are fre-

\section{Qualité de l'air ambiant et santé des humains : Notions courantes $-2^{\mathrm{e}}$ partie}

RÉSUMÉ : Cette deuxième et dernière partie se poursuit avec la mise au point d'un cadre permettant de comprendre les questions en matière de qualité de l'air ayant un rapport avec la santé des humains. Les effets reconnus de la pollution de l'air sur la santé sont décrits et les controverses courantes à propos de l'ozone et des matières particulaires inférieures à $10 \mu\left(\mathrm{PM}_{10}\right)$ sont brièvement exposées. Les méthodes épidémiologiques servant à étudier les effets de la qualité de l'air sont discutées en comparant les étudesclés récemment menées au Canada. Les études comparatives de prévalence ne sont pas les plus appropriées en matière d'épidémiologie de la qualité de l'air mais sont fréquemment citées et menées au Canada comme si elles faisaient autorité. Les conséquences de l'établissement de normes de qualité de l'air ou d'objectifs basés sur ces études ou visant à satisfaire des niveaux arbitraires de risque sur la santé sont examinées. Actuellement, les résultats des recherches les plus élaborées ne sont pas en faveur de normes sur la qualité de l'air basées sur le risque. Une politique d'amélioration continue s'avère une meilleure protection à la fois pour la santé des humains et pour l'environnement.

quently cited in the literature. Table 1 presents a list of the best documented air pollution disasters. The circumstances responsible for these catastrophes still exist in many parts of the world, particularly in developing countries. In Canada the prospect of an incident such as a Donora or a Bhopal is remote but by no means nonexistent. An organization that represents a partnership between the Canadian government and

Correspondence and reprints: Department of Public Health Sciences, University of Alberta Faculty of Medicine, 13-103 Clinical Sciences Building, Edmonton, Alberta T6G 2G3. Telephone 403-492-6291, Fax 403-492-0364, e-mail Tee.Guidotti@ualberta.ca 
TABLE 1

Air pollution incidents with documented excess mortality

\begin{tabular}{|c|c|c|c|}
\hline Location & Dates & Deaths* (excess) & Associated pollution \\
\hline Meuse Valley, Belgium & December 1-6, 1930 & 60 dead & Presumed heavy $\mathrm{SO}_{2}$ \\
\hline Donora, PA & October 26-31, 1948 & 20 dead & Heavy $\mathrm{SO}_{2} ; \mathrm{ZnNH}_{2} \mathrm{SO}_{4}$ may have been present \\
\hline London, UK & December 5-9, 1952 & (about 4000) & $\begin{array}{l}\text { Coal-fuelled home heating and industrial emissions, high } \\
\mathrm{SO}_{2} \text { and particulates, sulphates }\end{array}$ \\
\hline London, UK & December 6, 1962 & (about 700) & $\begin{array}{l}\text { Advance warning issued to ill and elderly thought to have } \\
\text { lowered mortality rate by permitting protective measures, } \\
\text { same exposures as in } 1952\end{array}$ \\
\hline
\end{tabular}

${ }^{*}$ Deaths directly attributed to episode or (in parenthesis) excess deaths over expected for the period

TABLE 2

Diseases or conditions for which air pollution exposure may be a contributing factor

\begin{tabular}{|c|c|c|c|}
\hline Effect & How air pollution may affect it & Associated factors & Diagnostic approach \\
\hline \multirow[t]{2}{*}{ Eye irritation } & $\begin{array}{l}\text { Specific effect of photochemical oxidants, } \\
\text { possibly aldehydes, or peroxyacetyl nitrates }\end{array}$ & $\begin{array}{l}\text { Susceptibility and awareness } \\
\text { differ }\end{array}$ & $\begin{array}{l}\text { Direct question; greatest effect at } \\
\text { times and places when } \\
\text { photochemical reactions are strong: } \\
\text { midday, summer, low latitudes }\end{array}$ \\
\hline & Particulate matter (fly-ash) as a foreign body & & History of 'speck in eye' \\
\hline Acute effects & $\begin{array}{c}\text { Direct irritative effects of } \mathrm{SO}_{2} \text {-particulate and } \\
\text { photochemical pollution or reflex reactions }\end{array}$ & $\begin{array}{l}\text { Cigarette smoking may have a } \\
\text { more than additive interaction }\end{array}$ & $\begin{array}{l}\text { Careful history and time-location } \\
\text { association }\end{array}$ \\
\hline Chronic effects & $\begin{array}{l}\text { Aggravation (increase in frequency or severity) of } \\
\text { cough or sputum associated with any sort of } \\
\text { pollution }\end{array}$ & Cigarette smoking, occupation & $\begin{array}{l}\text { Use of standard interview, lung } \\
\text { function }\end{array}$ \\
\hline Asthma & $\begin{array}{l}\text { Bronchoprovocation from any respiratory irritant, } \\
\text { possibly on reflex basis; associated most } \\
\text { strongly with } \mathrm{SO}_{x}, \mathrm{O}_{3}, \mathrm{NO}_{2}\end{array}$ & $\begin{array}{l}\text { Usually pre-existing respiratory } \\
\text { allergy or airway reactivity }\end{array}$ & $\begin{array}{l}\text { History, serial lung function or } \\
\text { provocative tests. Prevention or } \\
\text { treatment by bronchodilators }\end{array}$ \\
\hline Headache & $\begin{array}{l}\text { Carbon monoxide sufficient to lead to more than } \\
10 \% \text { carboxyhemoglobin }\end{array}$ & $\begin{array}{l}\text { Smoking may also increase } \\
\text { carboxyhemoglobin but not } \\
\text { enough to lead to headache }\end{array}$ & $\begin{array}{l}\text { Measured level of carboxyhemoglobin } \\
\text { in blood. History of } 1 / 2 \mathrm{~h} \text { or more in } \\
\text { parking garage or other enclosed } \\
\text { space with automobile exhaust }\end{array}$ \\
\hline Lead toxicity & $\begin{array}{l}\text { Neurotoxicity may be expressed as learning } \\
\text { disorder or reduction in IQ level; extensive } \\
\text { reevaluation of this problem in recent years }\end{array}$ & $\begin{array}{l}\text { Close proximity to lead source; } \\
\text { exposure at home }\end{array}$ & $\begin{array}{l}\text { Childhood problem; much reduced } \\
\text { now that lead removed from } \\
\text { gasoline. Blood lead, if suspected }\end{array}$ \\
\hline
\end{tabular}

$\mathrm{SO}_{\mathrm{x}}$ Oxides of sulphur

industry has been created to address such issues: the Major Industrial Accident Coordinating Council of Canada (265 Carling Avenue, Ottawa, Ontario K1S 2E1).

Table 2 presents a concise summary of major health effects caused or exacerbated by ambient air pollution. The table does not include numerous episodes of isolated place of toxic gas during industrial or transport accidents, which are much more common and conceptually more straightforward to deal with (2).

Although cigarette smoking is by far the leading single cause of chronic respiratory disease, many smokers search for other explanations in an attempt to deny the need to quit the habit. Although air pollution may make their symptoms worse, it is almost never the primary or sole cause of serious respiratory disease among smokers.

\section{Effects observed in populations}

Human health effects are well known to occur as a result of exposure to air pollutants (1,3-9). These health effects are better characterized for populations than for individual patients.

There are four general categories of human health effects associated with air pollution: mortality; respiratory symp- toms; cancer; and systemic effects. The following section summarizes many of the known effects and the findings of more recent studies.

Mortality: Mortality (number of deaths in a given period per 100,000 population) is obviously an extreme measure of health impact. An elevated mortality rate associated with a particular exposure suggests that the exposure is contributing to the deaths of susceptible people in the population. Several studies have provided persuasive evidence that adverse air quality is directly linked to mortality (10-15). This is most obvious in extreme urban settings such as Los Angeles (16) and the Czech Republic (12), in episodes of exceptional exposures to air toxics such as the London 'killer fogs' (17), and in the coincidence of adverse air quality and heat waves as in New York City. There is some evidence emerging that exposure to particulates is also correlated with mortality, even below existing air pollution guidelines (11). The mechanism by which relatively small increases in particulates smaller than the cutoff of the respirable range of $10 \mu \mathrm{m}$ $\left(\mathrm{PM}_{10}\right)$ are associated with increases in mortality is unknown, because the change in mortality is not all due to respiratory or cardiovascular disease. 
Respiratory disorders: Respiratory symptoms are the most common effects of air pollution of all types. Common symptoms include cough, which may be productive, nose and throat irritation, and mild shortness of breath (18). These respiratory symptoms are often associated with eye irritation and a sense of malaise. Fever is not a feature of air pollution exposure but exacerbation of allergic symptoms often is. Athletes often report that their performance is off and that they tire more rapidly when they exercise during periods of high pollution levels. Even at low exposure levels, ozone is associated with shortness of breath and reduction in vital capacity and forced expiratory flows in athletes, within the range of normal pulmonary function (19). This is consistent with a known effect of ozone in stimulating airways reflexes that inhibit full inspiration (20).

Asthmatics and patients with chronic obstructive pulmonary disease (COPD) often experience worsening of their symptoms during air pollution episodes. Although acute upper and lower respiratory tract infections appear to be more frequent in residents of areas with higher pollution levels, it is impossible to judge the contribution of this factor in reducing host defences in the individual case. Respiratory effects of air pollution, particularly complicating chronic bronchitis, may place an additional strain on cardiac function as well. There is evidence to suggest that older subjects are more resistant to the effects of photochemical air pollution in producing symptoms, however (21). Children, although they seem equally affected by the exposure to ozone, do not seem to report symptoms as readily as adults (22). Although it is clear that certain air pollutants aggravate existing reactive airways disease, it is not yet established that ambient air pollution at modern levels can cause asthma de novo. Indeed, the extant evidence seems to make this appear unlikely (3).

Bates and Sizto (23) demonstrated an association between both asthma and nonasthma respiratory admissions to hospital and 'acid summer haze' in southern Ontario. However, they could not separate the potential effects or interactions of ozone, sulphate or humidity. Subsequent studies investigating this effect on healthy human subjects have suggested that ozone rather than sulphate is associated with increased airways reactivity (24).

Mucosal irritation in the form of acute or chronic bronchitis, nasal tickle or conjunctivitis is characteristic of high levels of air pollution, although individuals vary considerably in their susceptibility to such effects. Frequently the eye irritation is particularly severe, usually in the setting of high levels of particulates (which may include quite large soot particles) or of high concentrations of photochemical oxidants and aldehydes (particularly peroxyacetyl aldehyde). This can make tasks requiring visual acuity and concentration difficult.

Recent studies suggest a close association between frequency and severity of asthma attacks and atmospheric oxidant and sulphate levels $(3,23,25,26)$. There is convincing evidence that exposure to certain air pollutants such as ozone and sulphates increases the frequency of episodes in asthmatic children (27-33); the evidence for adults is weaker for these pollutants $(27,34,35)$ but is well established for nitro- gen dioxide (32,36-39). However, this effect appears to occur in people who already have asthma. It has not been shown that exposure to these air pollutants causes asthma. In a major study that documented asthma prevalence in children in 10 rural communities in Canada with a gradient of ozone exposure, there was no demonstrable difference in prevalence or symptom frequency (40). Asthma is known to be associated with many risk factors that are more likely to be causal, singly or in combination: heredity, childhood respiratory tract infections, allergy, indoor air pollution and (weakly) cigarette smoking in the home. There are many other factors that provoke asthmatic episodes: cold air, exercise, respiratory tract infections and exposure to allergens in people with allergies (41). Within the typical levels of air pollutants encountered in Canada, it is unlikely that exposure to air pollution accounts for more than a small fraction of asthmatic episodes, although possibly more in the summer and in certain individuals $(28,29)$. This overall view of attribution seems to be supported by the available data (42).

Chronic bronchitis is a predictable effect of air quality but only at high exposure levels, especially to particulates and sulphur dioxide (the constituents of the London 'killer fogs'), and among nonsmokers. However, recent studies have suggested a correlation between ozone levels and nonspecific respiratory symptoms compatible with a low grade acute inflammatory process (30). Patients with chronic bronchitis may also have an increased cough. What is probably happening is that a very low grade degree of bronchitis is causing these symptoms, but it is not severe or prolonged enough to become chronic and symptomatic (43). In modern times, the classically productive chronic bronchitis has ceased to be a common respiratory condition and new cases are very unlikely to be primarily due to adverse ambient air quality.

Chronic obstructive lung disease, a diagnostic category that includes chronic bronchitis, but is more often emphysematous and associated with cigarette smoking, has been shown to be exacerbated during relatively heavy pollution episodes involving reducing air pollution (44), which is not commonly a problem in Canada. The effect on emergency room visits was only 6 to $9 \%$, seasonally adjusted (45), and was small for changes in pulmonary function (34). There is evidence to suggest that COPD among nonsmokers, which is uncommon, is associated with air pollution, both reducing air pollution and photochemical smog $(46,47)$. It had been thought that this might be due to a denaturing effect on alpha1-proteinase inhibitor activity (48) but there is also evidence that this is not the case (49).

Respiratory tract infections, or more accurately differential rates of these common viral infections, are probably the most sensitive effect of adverse air quality to express itself in clinical disease. It is well known that the 'attack rate' (how much of the population gets the disease in a particular period of time) is greater among children exposed to certain air toxics, particularly nitrogen dioxide and possibly ozone (50). There is good evidence that exposure to nitrogen dioxide in particular is associated with reduced host defences. If people are exposed to an air toxic at the time that they are infected 
with a virus against which they have no acquired immunity, they may be more likely to get the respiratory tract infection than they would otherwise, but the difference in numbers is small compared with the much large number who would get the infection regardless. The increased attack rate associated with exposure to nitrogen dioxide is well established (51); one would expect the same effect from ozone because of the similarity of its action. There is a large body of experimental literature confirming that nitrogen dioxide does indeed impair host defences against viral and bacterial infections in animals (52-54).

Perhaps reflecting effects related to both decompensation of COPD and compromised host defences, ozone and PM10 have been reported to be associated independently with increased hospitals admissions for pneumonia in the elderly (55).

Cancer: Cancer has always been a major theoretical concern in ambient air quality. Certainly, there are known carcinogens among the volatile organic compounds in ambient air pollution, principally benzene, benz(a)pyrene and 1,3butadiene (56). However, there is little evidence to suggest that community air pollution is a significant cause of cancer except in unusual cases of point-source emissions, such as smelters, where known carcinogens, particularly arsenic, may play a causal role in locally elevated risks for lung cancer. There is a strong suggestion in the experimental literature that exposure to oxidant air pollution may increase the frequency of metastases to the lung of established cancers $(57,58)$. However, the evidence for a direct connection between lung cancer and ambient urban air pollution is weak and limited to situations of appallingly bad air quality (59). Several studies that initially suggested such an association have since been dismissed because of methodological problems $(60,61)$. Local release of air toxics constitute a different problem, akin to a point-source outbreak, and risk assessment must be based on the particular emissions in question (56). There is evidence, for example, that residents of communities near smelters, with emissions of metals including arsenic, may have increased rates of lung cancer (61).

Systemic effects: Central nervous system effects and possibly learning disabilities in children may result from accumulated body burdens of lead, to which air pollution contributed a large fraction before removal of lead from gasoline in North America. Screening for lead intoxication should be part of the diagnostic work-up of all children with suspected learning disabilities, particularly in view of recent evidence suggesting that the behavioural toxicity of lead is much greater than was appreciated in the past. The addition of organic manganese compounds to gasoline to substitute as an octane booster has raised concerns about the potential for neurotoxicity from this light metal, toxicity which is known to be associated with a syndrome resembling Parkinson's disease (62). The investigation of the safety of manganese additives in gasoline is a major topic of investigation by Health Canada in its Bureau of Chemical Hazards in Ottawa.

Acute toxicity from carbon monoxide is more often a problem in indoor air pollution from sources of incomplete combustion, such as poorly ventilated stoves. However, in cases of prolonged exposure in vehicular traffic it is possible for carboxyhemoglobin levels to rise to levels sufficient to cause headaches and angina in persons with coronary artery disease $(63,64)$. In Canada, exposure to carbon monoxide is a serious episodic indoor air quality problem but ambient levels in urban areas are not considered to be a major problem. Elevated levels are encountered most often in Toronto, Montreal, St John's, Edmonton and Calgary (65).

\section{STUDIES OF AIR QUALITY AND HUMAN HEALTH}

Studies of air quality and human health have emerged since 1955 as a distinct area of specialization combining toxicology, epidemiology, atmospheric chemistry, physiology and environmental risk management. Such studies were pioneered in the 1950s and 1960s by Dr John R Goldsmith, then at the California Department of Health $(5,66-68)$. The essence of air quality studies is to combine these disciplines in a comprehensive approach that answers questions. In air quality studies, a single disciplinary approach applied in isolation is bound to fail.

Past experience with scientific studies of air quality has been mixed. The most common drawback has been a failure to see the big picture while focusing on one aspect of air quality and human health. Centres of excellence, such as the Six Cities Study team at Harvard University, avoid these inadequacies by teamwork and design their studies carefully and individually to derive useful data regardless of the scientific outcome (69). A committee of the National Academy of Sciences has reviewed the approaches and appropriate methods of epidemiology applied to air quality studies and has produced a useful report (70). A consistent recommendation throughout the report is to understand the exposure and the outcome of interest before designing the study.

The CHESS studies: A good example of an approach that ultimately failed is the experience of the Community Health and Environmental Surveillance System (CHESS), a series of large scale and very expensive epidemiological investigations conducted in the 1960s and early 1970s, and on which the primary ambient air quality standards adopted in the 1970 US Clean Air Act and its amendments were based or validated (51,71-75). These studies are now widely regarded as inadequate and have had to be supplemented by considerably expensive additional work $(54,67,76,77)$. The problems associated with the CHESS studies were not in the epidemiology or formal study design. In fact, the basic study designs used in air quality investigations have hardly changed. The principal investigators of CHESS, especially Dr Carl Shy, remain among the most respected figures in environmental epidemiology today, largely because they mastered the difficult lessons of the CHESS studies. Rather, the relative failure of the CHESS studies had more to do with lack of understanding at the time of fundamental issues in exposure assessment, physiology, host defence mechanisms in the respiratory tract, atmospheric chemistry and inadequate toxicological models for interpreting the epidemiological data. In particular, the investigators overlooked the critical role of indoor air quality 
in contributing to total exposure and this threw off their exposure assessment in almost every study.

Canadian studies: Canada's past experience in conducting large scale studies of the same magnitude as the CHESS studies has been very mixed, for many of the same reasons. The studies by Bates and colleagues probably represent the best of this experience. The most problematical Canadian investigations related to air quality, however, were conducted in and around Pincher Creek, Alberta. It is worthwhile summarizing and comparing the two research approaches.

Bates and colleagues (42) have conducted a series of studies in Ontario since 1978 relating air quality and human health. These documented an 'acid summer haze' effect consisting of increased hospital admissions for respiratory disorders associated in the summer months with conditions of relatively high ozone and high sulphate, exceeding Canadian maximum acceptable guidelines but remaining within American ambient air quality criteria (23). The association was soon confirmed by similar studies done in New Jersey (78) and in Montreal (79), where ozone was the major air pollutant. A similar study in Toronto, however, suggested a more pronounced effect associated with sulphates and aerosol acidity (80). Other investigators in Ontario found similar results (81). Both asthma and nonasthmatic diagnoses were obviously affected, but not nonrespiratory disorders, although a reanalysis of the Ontario data subsequently showed a weak effect for motor vehicle accidents as well (82), consistent with much earlier studies (83).

The initial study could not distinguish between the effects of the two pollutants, but subsequent reanalysis provided circumstantial evidence that it was most likely to be ozone or a third, unmeasured pollutant. Human experimental studies conducted to resolve this issue suggest that ozone is more likely than sulphate to cause these effects and would be sufficient (24). Comparable studies in Vancouver also implicated ozone as a candidate in provoking asthma attacks requiring emergency room visits (26).

The 'acid summer haze' effect is generally not a strong determinant of respiratory health, if hospital activity accurately reflects episodes of decompensation. Only about $6 \%$ of the variance is explained by the association in the Ontario data (42). The effect of the acid aerosol in Toronto appears to be much greater (84), apparently because unusual conditions favour extremely elevated and prolonged acid aerosol concentrations in populated areas (80). Most urban acid aerosols are neutralized to a large extent by ambient ammonia from anthropogenic sources, but air masses carrying acid aerosols from United States sources pass over the ammonia-poor Great Lakes directly into downtown Toronto.

The most recent generation of studies examining air quality and health effects have relied heavily on indicators of hospital activity as surrogate measures for disease outcomes. This is illustrated by the studies of Bates and colleagues. This reliance on hospital activity has been criticized as a potential methodological flaw, on several grounds $(82,85)$. These include, first, issues of the appropriate analysis of time series data (described as 'statistical problems' but actually based on fundamental underlying toxicological assumptions); second, changes in hospitalization, treatment or diagnostic practices; third, seasonal trends and variable weather conditions; fourth, bias introduced by geographic variability in insurance coverage; and fifth, the 'ecological fallacy', a concept in epidemiology referring to one's inability to relate individual outcome with personal exposure to the risk factor in question when analyzing group data from a heterogenous population. The criticisms apply with variable strength to the different types of studies: cross-sectional, time series and incident reconstructions.

However, this is not the real problem. It is unlikely that the pattern of demand for hospital services, such as hospitalization and emergency room visits, would have changed appreciably over the short time span of most studies (most under 10 years), although the absolute number of visits at a given time certainly would have. In this sense, hospital services are only an indicator of the underlying trend in acute exacerbation of respiratory illness or other ill-health. The real fallacy is to treat hospital services as if they were well-defined outcomes, such as episodes of asthma, or changes in pulmonary function rather than simply general indicators of morbidity and decompensation among a subset of the general population.

As Bates (86) has aptly pointed out, the real issue is one of coherence: do the various indicators and outcome measurements point in the same direction? Hospital services and the databases enumerating them compare favourably with other data sources, such as death certificates, in precision of diagnosis (87). The major difficulty is therefore likely to be one of variable 'signal strength' in using hospital services as indicators of acute decompensation, not one of substantial distortion of the signal itself.

The utility of mortality, indicators of morbidity and hospital services data lies primarily in the demonstration of an association - the actual magnitude of response (termed 'elasticity' in the literature) varies among communities and by season. There are too many uncertainties inherent in the analysis (85), the relatively weak correlations involved (82), the variability in reported 'elasticity' from location to location, and the obvious confounding and modifying effects of other risk factors in respiratory health to take the relationship as an absolute, generalizable measurement valid for all locations. At best, one can suggest a magnitude of impact specific to a given location but it is questionable whether risk or cost estimates (eg, 16) can be extrapolated from one city to another.

These studies combine the essential features of an appropriate epidemiological approach to air quality studies: exposure assessment, rational toxicological modelling, defensible and interpretable indicators of health outcomes, demonstration of an exposure-response relationship and efforts to achieve coherency. They were not limited to small area comparisons in prevalence or health status surveys, both of which are very inefficient ways to study air quality and human health (70). Their principal drawback is that they are potentially subject to the 'ecological fallacy'. However, even this 
disadvantage is countered by the fact that adverse ambient air quality, unlike lifestyle characteristics or even drinking water quality, is a shared, common-source exposure for all residents of a particular area. Not every one drinks tap water daily, and some people do spend a great deal of time indoors, but almost everyone outside of an institution breaths outdoor air sometime during the day.

The Pincher Creek studies were a series of investigations culminating in the so-called 'Medical Diagnostic Review' (MDR). The MDR was probably the largest study of its type ever conducted in Canada, and at $\$ 3.7$ million was almost certainly the most expensive. It was sponsored by the Acid Deposition Research Program, a cooperative effort by the Alberta provincial government and industry to assess the environmental impact of emissions of acid-forming gases, predominantly sulphur and nitrogen compounds.

For 30 years, the residents of the Pincher Creek area had been vocally concerned about the effects of emissions from sour (sulphur-containing) natural gas plants, wells and pipeline leaks on their health and that of livestock in the area. At first, the issue was restricted to a handful of local families living downwind of the sour gas plants who had observed what they felt were serious health problems among their children (including a case of near-sudden infant death) and livestock. This combination of social factors had given rise to a high level of community awareness and organization. Community concern reached the point at which it had to be dealt with in some definitive way.

Before the MDR, a health study in the Twin Butte area was conducted using questionable methods involving hair analysis for trace metals. It suggested a difference that might have been due to toxic exposures, although this was clearly an overinterpretation. This earlier study is now considered invalid but it aroused community concern. It had the effect of reinforcing the conviction of community residents that something was wrong. In order to resolve the issue once and for all, the decision was made to conduct a comprehensive community-wide health status survey. This was the MDR, an extensive battery of screening tests conducted in the field on 2157 residents of the Pincher Creek area and a similar number in two comparison areas of southern Alberta.

The basic strategy of the MDR was to simplify the problem to one basic issue: Using a battery of the most sensitive screening techniques available, is there evidence for a significant difference in health status between residents of the affected area and residents of a suitable comparison area? Repeatedly, residents of the area were told that the study was not designed to investigate the effects of sulphur-containing emissions. The MDR was expressly designed to identify any departure from expected health status in the community. For this reason, no environmental monitoring was conducted at the time of the study (88). It should be noted that at the same time that the MDR was being conducted, a committee of the National Academy of Sciences in the United States concluded that the approach of comparing geographical differences in prevalence as "of limited interest" and described the relationship of such studies to air pollution concerns as 'indirect' (70).
The results of the MDR were announced publicly at meetings in Pincher Creek in 1986. Residents were informed that no objective evidence was found for any difference in health status between their area and the reference areas. Their overall health status was quite good, comparable with other rural Albertans. They were further informed that a small difference existed in subjectively reported symptoms, possibly indicative of greater concern and awareness of personal health that may result from years of living in a state of uncertainty (88). However, the more recent publications from this study appear to contradict what the community was told (89).

Children aged five to 13 years in the affected area were reported to have a higher frequency of respiratory symptoms than those in the reference sample $(34.5 \%$ of 113 versus $6.8 \%$ of 353 ). Symptoms included cough, productive cough, wheezing and shortness of breath. The frequency of these complaints correlated with estimated exposure levels based on models constructed from environmental data originally collected to evaluate acid deposition at ground level for atmospheric dispersion studies. Adults did not show this effect. Neither adults nor children showed a corresponding difference in pulmonary function (90).

Because exposure was not assessed at the time of the study, the investigators had no way of developing an exposure-response relationship, an analysis that is critical to the toxicological interpretation of epidemiological studies. However, they did model area-wide exposure using data from 10 years of records on the cumulative precipitation of sulphur-containing compounds as sulphate by the 'candle' or lead dioxide method, collected by the Alberta Environmental Laboratories to monitor total sulphur release from sour gas plants. These were data on total atmospheric sulphur compounds (assumed to be sulphur dioxide and hydrogen sulphide), collected for another purpose. This was not a standard air quality reference method (91) and cannot identify peaks, duration of elevated readings or current levels of exposure at the time the screening tests were conducted. The method has distinct limitations as surrogate measurements for modelling ambient air concentrations of a dispersed gas at the time of the MDR. The data have no obvious relationship to ambient hydrogen sulphide levels. They do not relate to the period of the study and cannot be correlated to symptoms occurring at the time of the study. Despite these limitations, the authors used the data to construct a crude exposure gradient and reported a possible association (90).

One implication of these data is that the children had adverse effects resulting in nonspecific respiratory symptoms, as reported, and that spirometry is not sufficiently sensitive to pick up effects at low exposure levels. Another explanation, however, is that parents of these children, being concerned, tended to recall symptoms selectively. A subsequent study found a strong positive association between reported respiratory symptoms and scores on the psychiatric instrument used in the screening battery, particularly on the scales indicating anxiety, anger and cognitive disturbances (92). The findings of this study, implying a subjective basis for symptom reporting, applied to the same population as the 
Ambient air quality and human health

previous study, which concluded that a health effect could not be ruled out. It is not at all clear which interpretation is correct and the essential information on exposure that would resolve the issue was not collected. However, it is easy to conceive of this as a situation in which emotionality would act as a true confounder in the epidemiological sense, related to both the exposure (because of concern over exposure to sour gas) and outcome (by modifying perceptions of health).

The MDR was not originally designed to test a hypothesis, only to document differences in health status between two populations. The concept was that the concerns of the community would be considered meaningful only if it could be established that the residents of Pincher Creek showed a difference in health status compared with the reference population. They did, but it was apparently not enough and psychological factors were shown to confound the relationship. Had the Pincher Creek study shown unequivocal positive findings, the investigation would certainly have had to move into a second phase, at considerable additional expense (although almost certainly less than for the MDR itself), to relate exposure to outcome. Although this second study would indeed have addressed community concerns, it would have done so years later, at a time when exposure assessment would have been even more difficult and after some of the children who were originally the cause of concern in the community had, in fact, grown up. As it happened, the findings were ultimately equivocal, but this was not sufficiently persuasive to result in a follow-up study. The question begs to be asked: Why was the correct study not done in the first place?

Locally in Alberta, the legacy of the MDR was unfortunate. Residents of the community believe that they were given contradictory messages. Some residents have expressed the opinion that the study was a smoke screen that obscured rather than clarified their concerns. Resources that could have been used to develop an infrastructure for environmental epidemiology were diverted to a low-yield community screening exercise. Health effects that may only be apparent in longitudinal studies or with focused testing would not have been detected with the clinical tests on which the MDR relied. The MDR is regularly cited locally as an example of how expensive and unrewarding environmental epidemiology can be and invoked as a reason not to consider further studies. It has cast a chill on further research in the field in Alberta.

However, the larger significance of the MDR in Canada is that it illustrated a more general tendency in Canada to design studies related to environmental concerns as community health surveys, rather than targeting known effects and basing such studies on a toxicological understanding of the agent in question (93). Community health surveys are a very useful approach in epidemiology, particularly in evaluating health services and identifying communities at risk. For a variety of good reasons, they are almost a Canadian specialty within epidemiology. A good community health survey may target subgroups at high risk and may well generate useful hypotheses for further investigation. However, these surveys have in-
TABLE 3

Ambient air quality objectives for Canada

\begin{tabular}{|c|c|c|c|}
\hline Objective & $\begin{array}{c}\text { Maximum } \\
\text { desirable }\end{array}$ & $\begin{array}{c}\text { Maximum } \\
\text { acceptable }\end{array}$ & $\begin{array}{c}\text { Maximum } \\
\text { tolerable }\end{array}$ \\
\hline \multicolumn{4}{|l|}{ Sulphur dioxide } \\
\hline $1 \mathrm{~h}$ average & 0.17 & 0.34 & - \\
\hline $24 \mathrm{~h}$ average & 0.06 & 0.11 & 0.31 \\
\hline Annual average & 0.01 & 0.02 & - \\
\hline \multicolumn{4}{|l|}{ Nitrogen dioxide } \\
\hline $1 \mathrm{~h}$ average & - & 0.21 & 0.53 \\
\hline $24 \mathrm{~h}$ average & - & 0.11 & 0.16 \\
\hline Annual average & 0.03 & 0.05 & - \\
\hline \multicolumn{4}{|l|}{ Ozone (oxidants) } \\
\hline $1 \mathrm{~h}$ average & 0.05 & 0.08 & 0.15 \\
\hline $24 \mathrm{~h}$ average & 0.015 & 0.025 & - \\
\hline Annual average & - & 0.015 & - \\
\hline \multicolumn{4}{|l|}{ Carbon monoxide } \\
\hline $1 \mathrm{~h}$ average & 5 & 13 & 17 \\
\hline $8 \mathrm{~h}$ average & 13 & 31 & - \\
\hline \multicolumn{4}{|l|}{ Particulates $\left(\mu \mathrm{g} / \mathrm{m}^{3}\right)$} \\
\hline $24 \mathrm{~h}$ average & - & 120 & 400 \\
\hline $\begin{array}{l}\text { Annual geometric } \\
\text { mean }\end{array}$ & 60 & 70 & \\
\hline \multicolumn{4}{|c|}{ Hydrogen sulphide (ppb) } \\
\hline $1 \mathrm{~h}$ average & 0.7 & 10.8 & - \\
\hline $24 \mathrm{~h}$ average & - & 3.6 & - \\
\hline
\end{tabular}

All units in part per million by volume (ppmv) unless otherwise specified. ppb Parts per billion

trinsic limitations, mostly related to their cross-sectional design. Their usefulness is limited in situations where one is seeking evidence of a small effect (in epidemiological terms) that is likely to be very time-dependent in a large population with variable exposure to the risk factor in question that is difficult to document or reconstruct. Community health surveys are inefficient for the purpose of documenting past health effects. Because of their cross-sectional design, they are not definitive in relating exposure to response.

As noted at the beginning of this article, there is now almost a half-century of experience with epidemiology applied to air quality studies. The principal effects of air pollutants are known or strongly suspected and they can be investigated in cost-effective targeted studies with more sensitive methods. The methods that have been developed since the 1950s are generally more appropriate to the investigation of human health effects associated with air quality than are broad community health surveys, even in situations where the effect of the exposure is unknown.

\section{RISK-BASED STANDARDS IN AIR QUALITY: THE PROBLEMS}

In Canada, local and regional air quality is compared with National Air Quality Objectives (Table 3) or their provincial counterparts. These objectives have the status of guidelines, representing desirable, acceptable and only tolerable levels of exposure. Their purpose is to set objectives for the establishment of 'source emission guidelines', which guide the stringency of controls actually placed on the source of emis- 
sions by industry on motor vehicle manufacturers. These air quality objectives are therefore very different from air quality standards such as those in the United States, where the federal government may force action on a local level by declaring an air quality management district a 'nonattainment area' and withholding federal funds. In Canada, environmental quality is primarily a provincial responsibility and there are only a few areas in the country that even come close to the poor air quality of many American nonattainment areas. The Canadian system was designed to be more advisory, consensual and indirect in its influence.

Risk-based objectives: A great deal of interest has been expressed recently in Alberta and elsewhere in the concept that air quality objectives can be set based on the risk of adverse health effects. This idea presumes a much closer relationship between specific health effects and specific pollutant levels than can be documented with the current state of the art. The idea is that by setting objectives or, in other jurisdictions, standards designed to attain targets for the reduction of human disease, principally asthma, air quality can be managed optimally and does not need to be reduced beyond a socially acceptable 'safe' level. There is some concern in the air quality community that moving to so-called 'risk-based' standards (or objectives) is likely to compromise efforts to enhance environmental quality and will limit progress in controlling air pollution.

An example of a risk-based standard or guideline is the maximum acceptable concentration for benzene in the Guidelines for Canadian Drinking Water Quality (94), which is set at $0.005 \mathrm{mg} / \mathrm{L}$ to conform to a de minimis cancer risk (no more than one in a million). However, benzene is a much better characterized chemical hazard than most and the outcome is defined.

The United States Environmental Protection Agency originally developed its primary ambient air quality criteria and later criteria for air toxics on the assumption that documented health effects could be used to set reasonable standards $(5,72)$. The assumption had been to set the standard on public health grounds and to let the technology follow (95). In recent years (since the Clean Air Act Amendments of 1990), the agency has modified this approach and now places greater emphasis on technology-based standards $(96,97)$. For most environmental standards, risk estimates are driven by cancer risk assessments. This is also generally true for air toxics. However, for ambient air quality, noncancer risks are more critical.

The use of human health effects to determine optimal levels of air quality (ie, allowable exposure levels consistent with an acceptable quality of life) is not easily defended given current technology. Human health effects are not particularly good indicators of air quality for a number of reasons. Except for mortality (deaths), human health is not continuously monitored by a system that can be used to track progress or deterioration in levels of exposure to air pollution. Even if it were, air quality is a secondary and probably often indirect determinant of human health, with the possible exception of acute asthma episodes. The establishment of a reliable reporting system is an expensive and difficult undertaking.

The most sensitive human health effects responding to air quality have been assumed to show 'threshold' effects. That is, they should show little direct correlation with environmental conditions at low levels but suddenly become apparent at high levels, in many cases higher than would be expected in most Canadian jurisdictions $(3,27)$. The existence of thresholds suggests that standards could be set to protect the majority in the population. However, the use of apparent thresholds for this purpose is rarely easy. Thresholds may be as often artefact as real, reflecting the sensitivity of detection of the method used to monitor health (98). Some people are much more susceptible than the majority and safety factors must always be incorporated. At least one major cause of air pollution, particulates, does not seem to show a threshold effect in more recent studies $(10,11)$. Indeed, within a wide range of exposures relevant to air quality guidelines, thresholds may be absent even for death or gross clinical illness $(10,81)$.

The effect of ambient air quality on human health is confused (or, in scientific terminology, 'confounded') by numerous other inhaled exposures, such as passive or active cigarette smoking, indoor air quality, respiratory tract infections and by heredity $(27,99-101)$. It is therefore difficult to discern a clear 'signal' through the 'noise', and the interpretation of epidemiological data to derive thresholds for air pollution standards is always a controversial and sometimes an arbitrary exercise.

Further confusing the picture is the suggestion that at least some acute adverse health effects may be triggered by the rate of change in pollutant concentration rather than by the absolute concentration. If true, this would force a change in the concept of thresholds and the manner in which air pollution levels are reported and statistically summarized. It would certainly make risk-based standards less tenable as a regulatory approach.

Direct associations between human health and air toxics have only been established for a few air toxics at the lower levels one expects to see in Canada under normal circumstances (ie, without an incident of release); however, studies of aggregate exposures to mixed air pollutants in urban settings show clear effects on mortality, chronic bronchitis and asthma. This means that changes in the frequency of these disorders generally cannot be used to identify which air contaminant or class of contaminants is out of control $(3,27,102)$.

Although certain human health conditions do seem to respond to changes in air quality, such as the frequency of asthma episodes with respect to ozone levels, the changes in these indicators are small compared with the base. In other words, most asthma episodes probably have little or nothing to do with ozone levels, but increased ozone levels do provoke an increase in asthma episodes in some individuals $(6,103)$.

Indicator-driven standards: Another approach closely related to risk-based standards but not necessarily involving 
formal risk assessment methods is to set standards based on indications of ecosystem damage (104). Human health effects are not the only or even the most sensitive indicators of air quality. Livestock and ecosystem effects, particularly on forests, appear to be at least as sensitive but have not been as extensively studied. The use of ecosystem indicators is generally further advanced for monitoring water quality than it is for air quality.

Biological exposure indicators are tests designed to detect small quantities of chemicals taken into the body during exposures or to detect small changes in the body's chemistry or function resulting from an exposure (8). There are about three dozen in common use, all developed for occupational health applications, not routine air quality monitoring. The most familiar are tests for exposure to lead, solvents and pesticides. One such family of tests, not yet in common use, can detect exposure to carcinogens of many types. There is some indication that some of these tests may become abnormal in extreme environmental conditions, such as contamination levels seen in Eastern Europe (eg, Romania) and the former Soviet Union (105). It is technically feasible for some of them to be used for air toxics at lower levels, but interpretation would be a problem and there would certainly be considerable inaccuracies in measurement at such low levels.

Continuous improvement: There is no shortcut to judgement in setting air quality standards. A particular concern is that the appeal of risk-based standards will win over in public policy despite the uncertain base of scientific evidence and that this policy will result in a halt to progress in improving air quality. This returns the discussion to the issues raised at the beginning of this discussion on the definition of 'clean air'. Like all economic activities, controlling emissions of air pollution at the source is subject to the law of diminishing re-

1. American Thoracic Society. Health Effects of Air Pollution. New York: American Lung Association, 1978.

2. Guidotti TL. Managing incidents involving hazardous substances. Am J Prev Med 1986;2:148-54.

3. Wardlaw AJ. The role of air pollution in asthma. Clin Exp Allergy 1993;23:81-96.

4. Gong H Jr. Health effects of air pollution. Clin Chest Med 1992;13:201-14.

5. Goldsmith JR. The usefulness of epidemiology in environmental health protection. Atmospheric pollution effects. Public Health Rev 1991;18:183-236.

6. Richards W. Effects of air pollution on asthma. Ann Allergy 1990;65:345-7.

7. Waller RE. Atmospheric pollution. Chest 1989;96(Suppl 3): 363S-8S.

8. Utell MJ, Samet JM. Air pollution and health. Am Rev Respir Dis 1988;138:1065-8.

9. Guidotti TL, Goldsmith JR. Air pollution and family health. Am Fam Physician 1983;27:165-72.

10. Dockery DW, Pope CA III. Acute respiratory effects of particulate air pollution. Ann Rev Public Health 1994;15:107-32.

11. Dockery DW, Pope CA III, Xu X, et al. An association between air pollution and mortality in six U.S. cities. N Engl J Med 1993;329:1753-9.

12. Bobak M, Leon DA. Air pollution and infant mortality in the Czech republic, 1986-88. Lancet 1992;340:1010-4. turns and increasing marginal cost (106). From a business perspective, it makes sense to stop when the air is clean enough. But when is the air 'clean enough'? Is it when the 'no observed adverse effect level' for any known human health effect is achieved? Is it when no adverse effect can be identified for any 'receptor' (used here in the ecological sense of target species)? Is it when a list of arbitrary air quality standards have been declared satisfied? The history of air quality studies aimed at identifying thresholds for human health effects suggests that this is one area of science that does not yield easy answers. In this case, the reason is that it is not at bottom a scientific question.

A decision on when to stop regulating air quality is a social decision based on perceptions of the cost, discomfort, disease-related suffering, aesthetic degradation, ecosystem damage and cultural measuring of air pollution. Public values are changing and environmental quality is much more appreciated now than in the past. Likewise, research in environmental sciences, in addition to human health, has documented increasingly subtle changes and has suggested that the order of magnitude of effects of air quality degradation is much greater than previously realized. Past experience suggests that environmental standards change with new information and that they are almost always revised downward. As a society learns, it inevitably demands greater control.

The alternative to a strategy of 'just enough' regulation is an open-ended policy of continuous improvement based on the best available control technology feasible to reduce emissions at the source and continuous review of standards in the light of new information. This may not be the least expensive approach but it is likely to be the approach that comes closest in the long run to achieving the working definition of clean air cited earlier in this review.

13. Kinney PL, Ozkaynak H. Associations of daily mortality and air pollution in Los Angeles County. Environ Res 1991;54:99-120.

14. Archer VE. Air pollution and fatal lung disease in three Utah Counties. Arch Environ Health 1990;45:325-34.

15. Guidotti TL, Mattson ME. Health risks associated with residence near a primary copper smelter: a preliminary report. Am J Ind Med 1980;1:365-74.

16. Hall JV, Winer AM, Kleinman MT, et al. Valuing the health benefits of clean air. Science 1992;255:812-6.

17. Godlee F. Air pollution: I. From pea souper to photochemical smog. BMJ 1991;303:1459-61.

18. Kulle TJ, Sauder LR, Hebel JR, Chatham MD. Ozone response relationships in healthy nonsmokers. Am Rev Respir Dis 1985;132:36-41.

19. Brunekreef B, Hoek G, Greugelmans O, Leentvaar M. Respiratory effects of low-level photochemical air pollution in amateur cyclists. Am J Respir Crit Care Med 1994;150:962-6.

20. Hazucha MJ, Bates DV, Bromberg PA. Mechanisms of action of ozone on the human lung. J Appl Physiol 1989;67:1535-41.

21. Drechsler-Parks DM, Bedi JF, Horvath SM. Pulmonary function responses of older men and women to $\mathrm{NO}_{2}$. Environ Res 1987;44:206-12.

22. Committee on Environmental Health (of the American Academy of Pediatrics). Ambient air pollution: respiratory hazards to children. Pediatrics 1993;91:1210-3.

23. Bates DV, Sizto D. Air pollution and hospital admissions in southern Ontario: the acid summer haze effect. Environ Res 
1987;43:317-31.

24. Linn WS, Shamoo DA, Anderson KR, Peng R-C, Avol EL, Hackney JD. Effects of prolonged, repeated exposure to ozone, sulfuric acid, and their combination in healthy and asthmatic volunteers. Am J Respir Crit Care Med 1994;150:431-40.

25. Marzin C, Le Moulled Y, Ancelle T, Juhel J, Festy B, Pretet S. Asthme, pollution atmospherique urbaine et meteorologie. Rev Mal Respir 1993;10:229-35.

26. Bates DV, Baker-Anderson M, Sizto R. Asthma attack periodicity: a study of hospital emergency visits in Vancouver. Environ Res 1990;51:51-70.

27. Abbey DE, Petersen F, Mills PK, Beeson WL. Long-term ambient concentrations of total suspended particulates, ozone, and sulfur dioxide and respiratory symptoms in a nonsmoking population. Arch Environ Health 1993;48:33-46.

28. Hoek G, Fischer P, Brunekreef B, Lebret E, Hofschreuder P, Mennen MG. Acute effects of ambient ozone on pulmonary function of children in the Netherlands. Am Rev Respir Dis 1993;147:111-7.

29. Hoek G, Brunekreef B, Kosterink P, van den Berg R, Hofschreuder P. Effect of ambient ozone on peak expiratory flow of exercising children in the Netherlands. Arch Environ Health 1993;48:27-32.

30. Ostro BD, Lipsett MJ, Mann JK, Krupnick A, Harrington W. Air pollution and respiratory morbidity among adults in Southern California. Am J Epidemiol 1993;137:691-700.

31. Roemer W, Hoek G, Brunekreef B. Effect of ambient winter air pollution on respiratory health of children with chronic respiratory symptoms. Am Rev Respir Dis 1993;147:118-24.

32. Koenig JQ, Covert DS, Smith MS, van Belle G, Pierson WE. The pulmonary effects of ozone and nitrogen dioxide alone and combined in healthy and asthmatic adolescent subjects. Toxicol Ind Health 1988;4:521-32.

33. Whittemore AS, Korn EL. Asthma and air pollution in the Los Angeles area. Am J Public Health 1980;70:687-96.

34. Pope CA III, Kanner RE. Acute effects of $\mathrm{PM}_{10}$ pollution on pulmonary function of smokers with mild to moderate chronic obstructive pulmonary disease. Am Rev Respir Dis 1993;147:1336-40.

35. Avol EL, Linn WS, Peng RC, Valencia G, Little D, Hackney JD. Laboratory study of asthmatic volunteers exposed to nitrogen dioxide and to ambient air pollution. Am Ind Hyg Assoc J 1988;49:143-9.

36. Bylin G, Hedenstierna G, Lindvall T, Sundin B. Ambient nitrogen dioxide concentrations increase bronchial responsiveness in subjects with mild asthma. Eur Respir J 1988;1:606-12.

37. Bylin G, Lindvall T, Rehn T, Sundin B. Effects of short-term exposure to ambient nitrogen dioxide concentrations on human bronchial reactivity and lung function. Experientia 1987;51:227-30.

38. Mohsenin V. Airway responses to nitrogen dioxide in asthmatic subjects. J Toxicol Environ Health 1987;22:371-80.

39. Bauer MA, Utell MJ, Morrow PE, Speers DM, Gibb FR. Inhalation of $0.30 \mathrm{ppm}$ nitrogen dioxide potentiates exercise-induced bronchospasm in asthmatics. Am Rev Respir Dis 1986;134:1203-8.

40. Stern BR, Raizenne ME, Burnett RT, Jones L, Kearney J, Franklin CA. Air pollution and childhood respiratory health. Exposure to sulfate and ozone in 10 Canadian rural communities. Environ Res 1994;66:125-42.

41. Gelber LE, Seltzer LH, Bouzoukis JK, et al. Sensitization and exposure to indoor allergens as risk factors for asthma among patients presenting to hospital. Am Rev Respir Dis 1993;147:573-8.

42. Bates DV, Sizto D. The Ontario Air Pollution Study: identification of the causative agent. Environ Health Perspect 1989;79:69-72.
43. Joad JP, Bric JM, Pino MV, Hyde DM, McDonald RJ. Effects of ozone and neutrophils on function and morphology of the isolated rat lung. Am Rev Respir Dis 1993;147:1578-84.

44. Sunyer J, Anto JM, Murillo C, Saez M. Effects of urban air pollution on emergency room admissions for chronic obstructive pulmonary disease. Am J Epidemiol 1991;134:277-86.

45. Sunyer J, Saez M, Murillo C, Castellsague J, Martinez F, Anto JM. Air pollution and emergency room admissions for chronic obstructive pulmonary disease: a 5-year study. Am J Epidemiol 1993;137:701-5.

46. Euler GL, Abbey DE, Hodgkin JE, Magie AR. Chronic obstructive pulmonary disease symptom effects of long-term cumulative exposure to ambient levels of total oxidants and nitrogen dioxide in California Seventh-Day Adventist residents. Arch Environ Health 1988;43:279-85.

47. Hodgkin JE, Abbey DE, Euler G, Magie AR. COPD prevalence in nonsmokers in high and low air pollution areas. Chest 1984;86:830-8.

48. Mohsenin V, Gee JBL. Acute effect of nitrogen dioxide exposure on the functional activity of alpha-1-protease inhibitor in bronchoalveolar lavage fluid of normal subjects. Am Rev Respir Dis 1987;136:646-50.

49. Johnson DA, Frampton MW, Winters RS, Morrow PE, Utell MJ. Inhalation of nitrogen dioxide fails to reduce the activity of human lung alpha-1-proteinase inhibitor. Am Rev Respir Dis 1990;142:758-62.

50. Jaakkola JJK, Paunio M, Virtanen M, Heinonen OP. Low-level air pollution and upper respiratory infections in children. Am J Public Health 1991;81:1060-3.

51. Shy CM, Creason JP, Pearlman ME, MCClain KE, Benson FB, Young MM. The Chattanooga school children experiment: effect of community exposure to nitrogen dioxide. II. Incidence of acute respiratory illness. J Air Poll Control Assoc 1970;20:582-92.

52. Graham JA, Gardner DE, Blommer EJ, House DE, Menache MG, Miller FJ. Influence of exposure patterns of nitrogen dioxide and modifications by ozone on susceptibility to bacterial infectious disease in mice. J Toxicol Environ Health 1987;21:113-25.

53. Miller FJ, Graham JA, Raub JA, et al. Evaluating the toxicity of urban patterns of oxidant gases. II. Effects in mice from chronic exposure to nitrogen oxide. J Toxicol Environ Health 1987;21:99-114.

54. Guidotti TL. Toxic inhalation of nitrogen dioxide: morphologic and functional changes. Exp Mol Pathol 1980;33:90-103.

55. Schwartz J. Air pollution and hospital admissions for the elderly in Detroit, Michigan. Am J Respir Crit Care Med 1994; 150:648-55.

56. Calabrese EJ, Kenyon EM. Air Toxics and Risk Assessment. Chelsea: Lewis Publishers, 1991.

57. Richters A, Kuraitis $\mathrm{K}$. Inhalation of $\mathrm{NO}_{2}$ and blood borne cancer cell spread to the lungs. Arch Environ Health 1981;36:36-9.

58. Richters A. Facilitation of cancer metastases by an air pollutant. J Surg Oncol 1981;17:159-62.

59. Witschi H. Ozone, nitrogen dioxide and lung cancer: a review of some recent issues and problems. Toxicology 1988;48:1-20.

60. Jacobson BS. The role of air pollution and other factors in local variations in general mortality and cancer mortality. Arch Environ Health 1984;39:306-13.

61. Brown LM, Pottern LM, Blot WJ. Lung cancer in relation to environmental pollutants emitted from industrial sources. Environ Res 1984;34:250-61.

62. Agency for Toxic Substances and Disease Registry (ATSDR). Toxicological Profile for Manganese (ATSDR TP-91/19). Atlanta: US Public Health Service, 1992.

63. Walden SM, Gottlieb SO. Urban angina, urban arrhythmias: 
carbon monoxide and the heart. Ann Intern Med 1990;113:337-8.

64. Heckerling PS, Leiken JB, Maturen A, Perkins JT. Predictors of occult carbon monoxide poisoning in patients with headache and dizziness. Ann Intern Med 1987;107:174-6.

65. Environment Canada. National Air Pollution Surveillance (NAPS), Annual Summary 1990 (EPS 7/AP/23). Ottawa: Ministry of Supply and Services, 1992.

66. Blanc P, Nadel JA. Clearing the air: the links between occupational and environmental air pollution control. Public Health Rev 1994;22:251-70.

67. Guidotti TL. The higher oxides of nitrogen: unintended products of technological progress. Environ Int 1980;3:69-77.

68. Goldsmith JR. Los Angeles smog. Sci J 1969;5:44-9.

69. Bresnitz EA, Rest KM. Epidemiologic studies of effects of oxidant exposure on human populations. In: Air Pollution, the Automobile, and Public Health. Washington: National Academy Press and the Health Effects Institute, 1988.

70. Committee on the Epidemiology of Air Pollutants [of the National Academy of Sciences]. Washington: National Academy Press, 1985.

71. Shy CM, Hasselblad V, Burton RM, Nelson CJ, Cohen AA. Air pollution health effects on ventilatory function of U.S. school children. Arch Environ Health 1973;27:124-8.

72. Shy CM, Finklea JF. Air pollution affects community health. Environ Sci Technol 1973;7:204-8.

73. Pearlman ME. Nitrogen dioxide and lower respiratory illness. Pediatrics 1971;47:391-8.

74. Shy CM, Creason JP, Pearlman ME, McClain KE, Benson FB, Young MM. The Chattanooga school children experiment: effect of community exposure to nitrogen dioxide. I. Methods, description of pollutant exposure, and results of ventilatory function testing. J Air Poll Control Assoc 1970;20:539-45.

75. Bates DV. Epidemiological basis for photochemical oxidant standard. Environ Health Perspect 1983;52:125-9.

76. Goldsmith JR. The usefulness of epidemiology in environmental health protection. I: Atmospheric pollution effects. Public Health Rev 1990;18:183-236.

77. Hauser TR, Shy CM. Position paper: NOx measurement. Environ Sci Technol 1973;6:890-4.

78. Cody RP, Weissel CP, Birnbaum G, Lioy PJ. The effect of ozone associated with summertime photochemical smog on the frequency of asthma visits to hospital emergency departments. Environ Res 199258:184-94.

79. Delfino RJ, Becklake MR, Hanley JA. The relationship of urgent hospital admissions for respiratory illness to photochemical air pollution levels in Montreal. Environ Res 1994;67:1-19.

80. Thurston GD, Gorczynski JE Jr, Currie JH, et al. The nature and origins of acid summer haze air pollution in metropolitan Toronto, Ontario. Environ Res 1994;65:254-70.

81. Burnett RT, Dales RE, Raizenne ME, et al. Effects of low ambient levels of ozone and sulfates on the frequency of respiratory admissions to Ontario hospitals. Environ Res 1994;65:172-94.

82. Lipfert FW, Hammerstrom T. Temporal patterns in air pollution and hospital admissions. Environ Res 1992;59:374-99.

83. Ury HK. Photochemical air pollution and automobile accidents in Los Angeles. Arch Environ Health 1968;17:340-5.

84. Thurston GD, Ito K, Hayes CG, Bates DV, Lippmann M. Respiratory hospital admissions and summertime haze air pollution in Toronto, Ontario. Consideration of the role of acid aerosols. Environ Res 1994;65:271-90.

85. Lipfert FW. A critical review of studies on the association between demands for hospital services and air pollution. Environ Health Perspect 1993;101(Suppl 2):229-68.

86. Bates DV. Health indices of the adverse effects of air pollution: the question of coherence. Environ Res 1992;59:336-49.

87. Delfino RJ, Becklake MR, Hanley JA. Reliability of hospital data for population-based studies of air pollution. Arch Environ Health 1993;48:140-6.

88. Spitzer WO, and the McGill Inter-University Research Group. The Southwestern Alberta Medical Diagnostic Review. Calgary: Acid Deposition Research Program, 1986.

89. Guiddotti TL. The riddle of Pincher Creek: gas refineries, community health, and the psychology of reporting health status. OEM Report 1989;11:83-5.

90. Dales RE, Spitzer WO, Suissa S, et al. Respiratory health of a population living downwind from natural gas refineries. Am Rev Respir Dis 1989;139:595-600.

91. Suess MJ, Craxford SR. Manual on Urban Air Quality Management. Copenhagen: World Health Organization Rgional Office for Europe, 1976:162-73.

92. Dales RE, Spitzer WO, Schechter MT, et al. The influence of psychological status on respiratory symptom reporting. Am Rev Respir Dis 1989;139:1459-63.

93. Spitzer WO, Baxter DW, Barrows HS, et al. Methylmercury and the health of autochthons in Northwest Quebec. Clin Invest Med 1988;11:71-97.

94. Federal-Provincial Subcommittee on Drinking Water of the Federal-Provincial Advisory Committee on Environmental and Occupational Health. Guidelines for Canadian Drinking Water Quality. Ottawa: Health and Welfare Canada, 1989.

95. National Commission on Air Quality. To Breathe Clean Air. Washington: US Government Printing Office, 1981.

96. Ohshita SB, Seigneur C. Risk and technology in air toxics control: California and the Clean Air Act amendments. Air Waste 1993;43:723-8.

97. Robinson JC, Pease WS. From health-based to technology-based standards for hazardous air pollutants. Am J Public Health 1991;81:1518-23.

98. Guidotti TL. Principles of occupational toxicology. In: Zenz C. Occupational Medicine. St. Louis: Mosby, 1994:70-84.

99. Infante-Rivard C. Childhood asthma and indoor environmental risk factors. Am J Epidemiol 1993;137:834-44.

100. Moseholm L, Taudorf E, Frosig A. Pulmonary function changes in asthmatics associated with low-level $\mathrm{SO}_{2}$ and $\mathrm{NO}_{2}$ air pollution, weather, and medicine intake: an 8-month prospective study analyzed by neural networks. Allergy 1993;48:334-44.

101. Skobeloff EM, Spivey WH, St Clair SS, Schoffstall JM. Influence of age and sex on asthma admissions. JAMA 1992;268:3437-40.

102. Pierson WE, Koenig JQ. Respiratory effects of air pollution on allergic disease. J Allergy Clin Immunol 1992;90:557-66.

103. McDonnell WF, Muller KE, Bromberg PA, Shy CM. Predictors of individual differences in acute response to ozone exposure. Am Rev Respir Dis 1993;147:818-25.

104. Krupa SV, Nosal MK, Legge A. Ambient ozone and crop loss: establishing a cause-effect relationship. Environ Poll 1994;83:269-76.

105. Levy B, ed. Air Pollution in Central and Eastern Europe: Health and Public Policy. Proceedings of the Second Annual Symposium on Environmental and Occupational Health During Societal Transition in Central and Eastern Europe, June 14019, 1991, Frydek-Mistek, Czechoslovakia. Boston: Management Sciences for Health, 1991.

106. Harrison D Jr. Who Pays for Clean Air? Cambridge: Ballinger, 1975. 


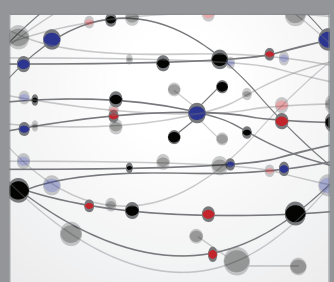

The Scientific World Journal
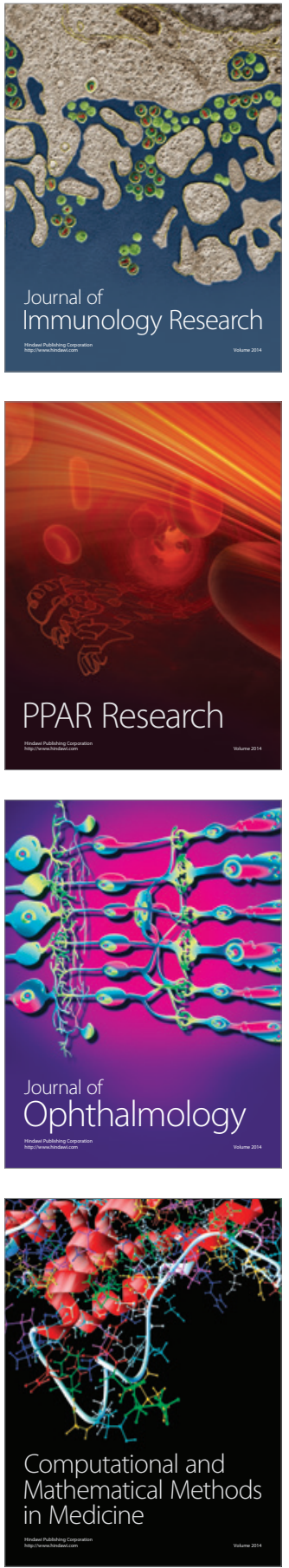

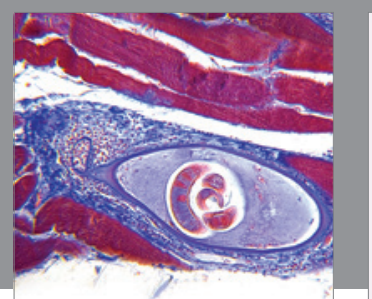

Gastroenterology Research and Practice

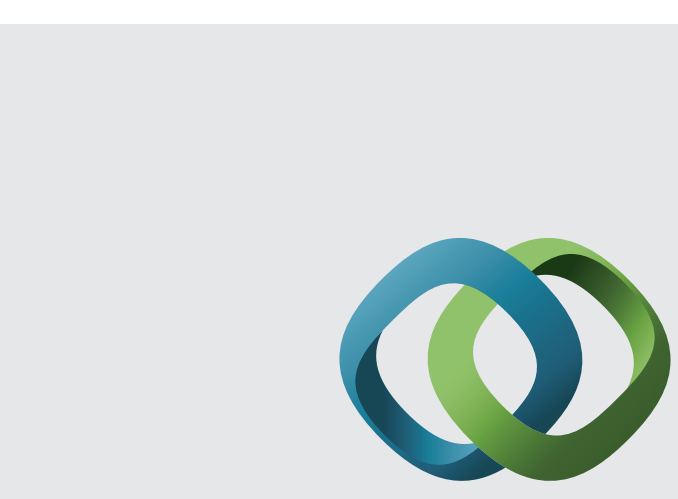

\section{Hindawi}

Submit your manuscripts at

http://www.hindawi.com
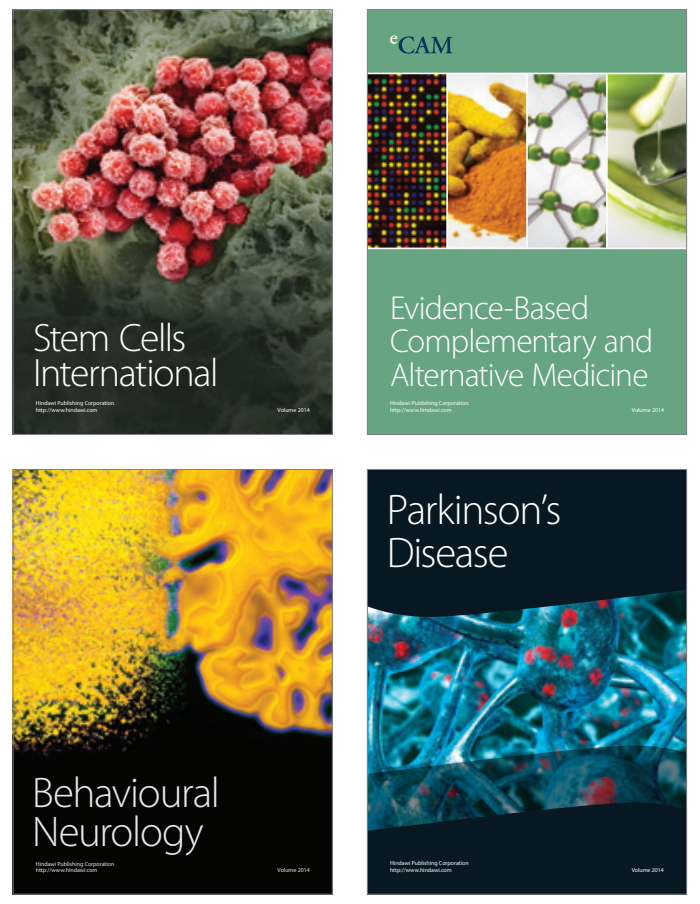
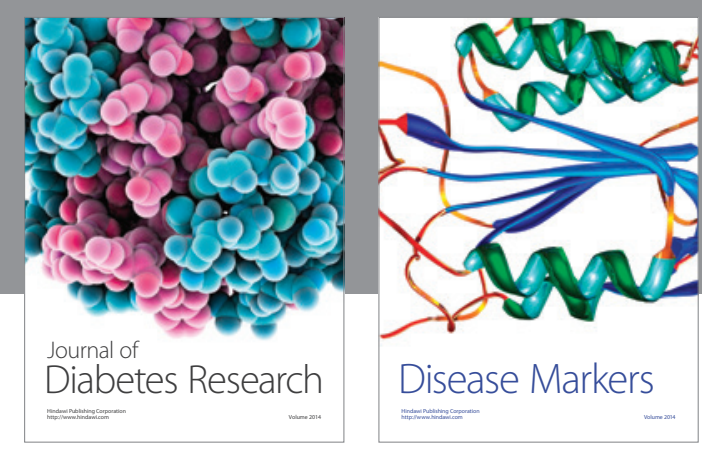

Disease Markers
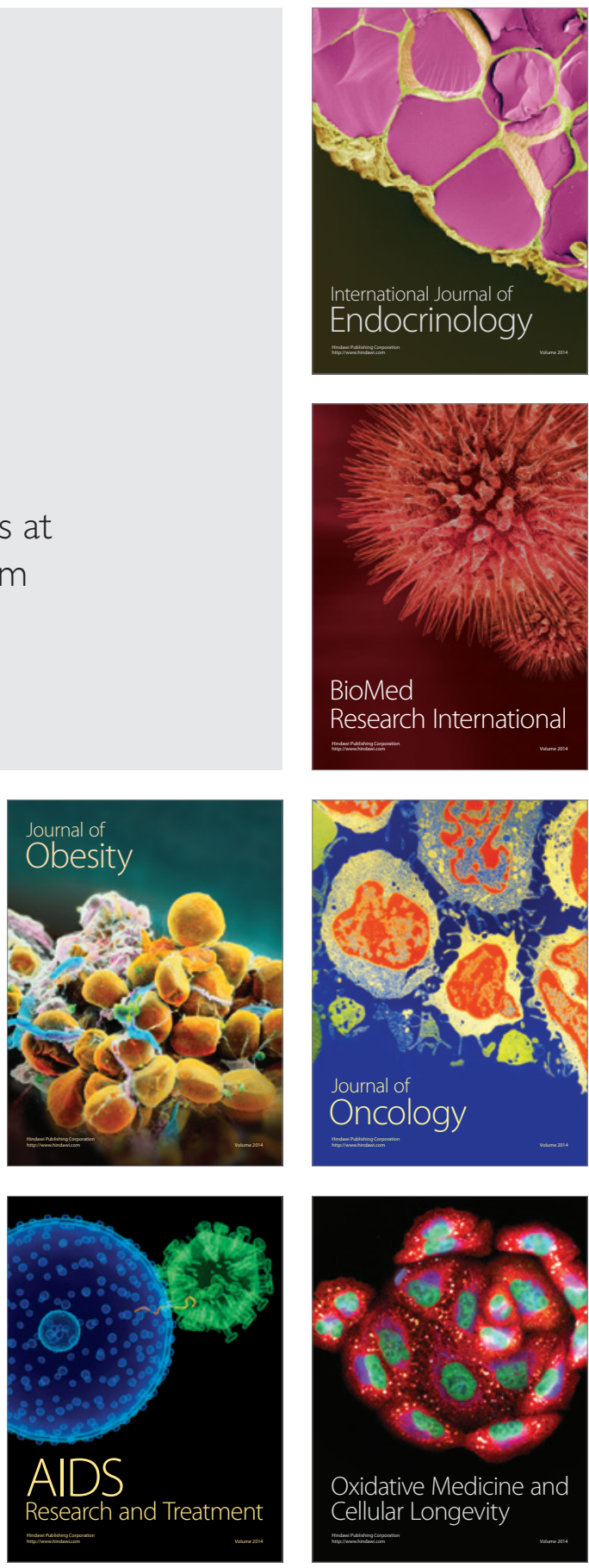